\title{
HÁROM ARCHEOFITON FAJ MÜTRÁGYA ÉRZÉKENYSÉGÉNEK MEGHATÁROZÁSA
}

\author{
Ecseri Károly - Honfi Péter
}

\begin{abstract}
Absztrakt: Az archeofitonok a szegetális fitoasszociációk tagjaiként fontos szerepet töltenek be a szántószegélyek biodiverzitásában. Ugyanakkor ezen taxonok száma jelentősen csökkent az elmúlt évtizedekben. Ennek okai a megváltozott mezőgazdasági termelés szerkezetben, ezen belül is például a megemelkedett mütrágya-alkalmazásban keresendők. Vizsgálatunkban három efemer szántóföldi faj mütrágya érzékenységét vizsgáltuk ex situ csírázásvizsgálattal, szabadföldi kísérlet keretében, valamint a prolin tartalom mérésének segítségével. A Papaver rhoeas esetében tapasztaltuk a legkedvezőbb csírázási paramétereket mind sebesség (7,32 nap), mind csírázási arány $(0,81)$ tekintetében. Ezek az értékek jelentősen romlottak az alkalmazott mütrágyás kezelés hatására (8,3 10,03 nap, csírázási arány: 0,72-0,39). A Cyanus segetum esetében lassabb kezdeti fejlödést tapasztaltunk, illetve a kezelés káros hatása ennél a fajnál is szignifikánsan kimutatható volt (átlagos csírázási idő: 12-13 nap, csírázási arány: 0,52-0,09). A Consolida regalis nem csírázott a kísérlet időtartama alatt. A Consolida regalis a műtrágyás kezelésre nagyobb virágzás intenzitással válaszolt. A prolin tartalom felhalmozódás magas sóérzékenységre utalt a Cyanus segetum esetében (0,49-0,54 mg/100 mg), mely ezen faj visszaszorulásának egyik oka lehet. Az eredményeink alapján a szarkaláb illetve a búzavirág esetében is magas érzékenységet tapasztatunk, mely a szántószegélyek védelmét indokolttá teszi hazánkban is.
\end{abstract}

\begin{abstract}
The archaeophytes have important role in biodiversity, because there are important members of field edge communities. At the same time, the number of these species decreased in recent decades. The changed structure of agricultural production (including fertilizer application increase) may be the reason for this. Aim of our study was to determine fertilizer sensitivity of three archaeophyte species using germination test, open field observation and proline content measurement. In case of Papaver rhoeas had the best germination parameters either speed (7.32 day) or germination rate (0.81). These values declined due to the applied fertilizer treatment (8.3-10.03 day, germination rate: 0.72-0.39). Cyanus segetum germinated slower (mean germination time: 12-13 day), and the harmful effect of treatment was also significant (germination rate: 0.52-0.09). Consolida regalis was not germinated in examination period. Higher blooming intensity was detected in open field in case of Consolida regalis due to fertilizer application. Salt sensitivity of Cyanus segetum is supported by proline accumulation $(0.49-0.54 \mathrm{mg} / 100 \mathrm{mg})$, which could be one reason of decrease. Based on our results, there is high sensitivity of fertilizers in case of larkspur and cornflower, which justify the protection of arable edges in Hungary.
\end{abstract}

Kulcsszavak: biodiverzitás, szántószegély, sóstressz, búzavirág

Keywords: biodiversity, field edges, salt stress, cornflower

\section{Bevezetés}

Az archeofitonoknak azokat a növényeket nevezzük, melyek eredetileg nem honosak az európai országok flórájában, de emberi hatásra betelepültek a Neolitikum vége és a középkor kezdete közötti időszakban. Az erős antropogén fejlődés miatt fennmaradásuk is nagymértékben függ a szántóföldi mezőgazdaságtól (Preston et al. 2004; Williamson et al. 2008).

Ezen taxonok veszélyeztetetté válásának okai között a mütrágyázási technológia megváltozása is kiemelkedő jelentőséggel bír (Albrecht 1995; Śarić et al. 2011). Ennél a tényezőnél direkt és indirekt hatásról is beszélhetünk a neofitonok és az 
archeofitonok tápanyagokért és fényért való kompetíciójában, például a Consolida regalis esetében (Svensson and Wigren 1986; Albrecht 1995). Szignifikáns csökkenést tapasztaltak az általunk vizsgált fajok esetében Németországban illetve Franciaországban is a XX. század második felében. A vizsgálatok alapján az alkalmazott kálium és nitrogén mütrágyák hatására jelentősen csökkent az antropochór fajok száma, míg az invazív neofitonok mennyisége növekedett (Baessler and Klotz 2006, Fried et al. 2009).

Vizsgálatunk célja három, indikátor fajként használható archeofiton mütrágya érzékenységének meghatározása. Az adatok segítségével szeretnénk ajánlást kidolgozni a szántószegélyek megóvására.

\section{Anyag és módszer}

\subsection{Ex situ csírázásvizsgálat}

Mindhárom fajból (Cyanus segetum Hill, Consolida regalis Gray, Papaver rhoeas L.) 4 ismétlésben 25 magot vizsgáltunk. A Cyanus és a Consolida magokat a Petri csészében két szürőpapír közé helyeztük, míg a Papaver rhoeas magokat nem fedtük le, a szürőpapír felületén helyeztük el. Az alkalmazott mütrágyát (N:P:K 6:12:24 + 8S) porrá őröltük és desztillált vízben feloldottuk. Az előkészített oldatokból (0,5, 1, 2 és $3 \mathrm{~g} / \mathrm{l}) 10 \mathrm{ml}-\mathrm{t}$ juttatunk a szürőpapírokra, míg a kontroll magok $10 \mathrm{ml}$ tiszta desztillált vizet kaptak. A csíráztatás szabályozott körülmények között történt (10 ó sötét periódus $10^{\circ} \mathrm{C}$-on, illetve 14 óra fényszakasz $20^{\circ} \mathrm{C}$-on, 1250 lux megvilágítás mellett). A kísérletet naponta értékeltük a 14-20 napos időszak alatt. A csírázott magoncokat (melyek gyököcskéje elérte a $2 \mathrm{~mm}-\mathrm{t}$ ) folyamatosan eltávolítottuk.

A kísérlet végén a következő paramétereket számoltuk ki:

- Csírázás gyorsasági index (PI): PI $=\operatorname{nd}_{2} \times(1,00)+\operatorname{nd}_{4} \times(0,75)+\operatorname{nd}_{6} \times(0,50)$ $+\mathrm{nd}_{8} \times(0,25)$, ahol $\mathrm{nd}_{2}, \mathrm{nd}_{4}, \mathrm{nd}_{6}$, és $\mathrm{nd}_{8}$ fejezi ki a csírázott magszámot a 2 ., 4., 6. és 8. napon (Zafar et al. 2015).

- Stressztürési index a csírázás alatt, \%-ban kifejezve: GSTI = (PI összes stresszelt mag/ PI kontroll magok) $\times 100$ (George, 1967), ahol a stresszelt magok a mütrágyás kezelést jelentik.

- Átlagos csírázási idő, napokban kifejezve: $M G T=\left(\sum\right.$ nixti $) / \sum n$, ahol ni jelenti a csírázott magok számát a ti időpontban, ti jelenti a csírázás kezdetéttől eltelt napok számát, $\mathrm{n}$ pedig a kísérlet végéig kikelt összes magszámot.

- Csírázási sebesség: GS=1/MGT×100 (Hartmann et al. 1997).

- Csírázási arány: a kísérlet végéig kikelt magok száma/összes magszám.

\subsection{Szabadföldi kísérlet}

A kísérlet helyszíne a Szent István Egyetem, Kertészettudományi Karának soroksári Kísérleti Üzeme és Tangazdasága volt. A talaj humuszban szegény, homokos fizikai féleségü, évelö gyomokkal erősen fertőzött. A kultivátorral megforgatott terület $50 \%$-ára $20 \mathrm{~g} / \mathrm{m}^{2}$ mennyiségü mütrágyát (N:P:K 6:12:24 + 8S) jutattunk ki, melyet ezt követően bedolgoztunk. A három vizsgált faj egyedeit külön parcellákban vizsgáltuk, melyek mérete 1,5×1,5 méter volt. Mindhárom fajból 200 magot 
jutattunk ki egy-egy kontroll és kezelt parcellára, három vetési időpontban (október 8-án, 14-én és 21-én). A magokat $2 \mathrm{~cm}$ vastag talajjal takartuk (kivétel a Papaver rhoeas, melyet felszínre vetettünk) és beöntöztük parcellánként 10 liter vízzel. A növények méretét (szélesség, hosszúság, magasság), fenológiai paramétereit és díszítő értékét vizsgáltuk a következő év július 14-éig (a téli időszakot leszámítva).

A díszítő értéket egy bonitálási skálán osztályoztuk, melynek kategóriái a következők:

5. Nagyon dekoratív, teljes virágzásban lévö, egészséges növény.

4. Mérsékleten díszitö, virágzás kezdetén/végén lévö, egészséges növény.

3. Közelesen dekoratív, vegetatív állapotban lévö, egészséges növény.

2. Dekorációs értékkel nem rendelkezö növény (fenológiai állapot, vagy stresszhatás miatt)

1. Nincs jelen a területen.

\subsection{Prolin tartalom meghatározás}

A prolinszint mérése Ábrahám et al. 2010 alapján történt. A szabadföldi kísérlet növényeiről két alkalommal vettünk levélmintát (november 24 és június 8 ). A mintákat $-20^{\circ} \mathrm{C}$-on tároltuk a felhasználásig. A mintákhoz (kb. $100 \mathrm{mg}$ friss tömegü levél) $3 \%$-os szulfoszalicil savat adtunk ( $5 \mu \mathrm{l} / \mathrm{mg}$ friss tömeg arányban), és lecentrifugáltuk őket $\left(5\right.$ perc, $\left.25^{\circ} \mathrm{C}, 15,689 \mathrm{~g}\right)$. Ezt követően a felülúszóból $100 \mu \mathrm{l}-\mathrm{t}$ hozzákevertünk a reakció elegyhez (100 $\mu \mathrm{l}$ 3\% sulfosalicil sav, $200 \mu \mathrm{l}$ jeges ecetsav and $200 \mu$ savas ninhidrin). 60 perc $96^{\circ} \mathrm{C}$-os hömérsékleten végzett inkubációt követően a reakciót jég segítségével megállítottuk. Ezután $1 \mathrm{ml}$ toluent adtunk az elegyhez és 20 másodpercig rázattuk. Az elválasztás után $(5$ perc) a kromofórt átpipettáztuk egy friss csőbe. Végül $520 \mathrm{~nm}$ hullámhosszon lemértük a minták abszorbanciáját egy GeneSys VIS-10 spektrofotométer segítségével. A prolin tartalmat a friss tömeg alapján számoltuk, egy standard koncentráció sor segítségével.

\subsection{Statisztikai kiértékelés}

$\mathrm{Az}$ adatok normalitás vizsgálata után egytényezős variancia-analízist (ANOVA) hajtottunk végre, majd a szignifikáns különbségeket a TUKEY teszt eredménye alapján értékeltük $\mathrm{P}<0,05$ szignifikancia szint mellett. Az elemzésekhez az SPSS 20 programcsomagot használtuk (IBM, New York, US).

\section{Eredmények és értékelésük}

\subsection{Ex situ csírázásvizsgálat}

A csírázás gyorsasági indexek vizsgálata alapján a Papaver rhoeas gyors kezdeti fejlődésünek bizonyult (Saeb et al. 2013), míg a Cyanus segetum csírázási sebessége a gabona fajtáknál lassabb, de hasonló a Centaurea nemzetség többi fajának értékéhez (Turkoglu et al. 2009). Az archeofitonok mütrágyázásra adott ilyen jellegü fejlődési válasza kapcsolatban lehet ezen taxonok megfogyatkozásával Európa több országában (Albrecht 1995; Svensson and Wigren 1986). A leglassabb fejlődést a 
Consolida regalis esetében tapasztaltuk. Ez a taxon nem csírázott a vizsgálati időszak alatt (14-20 nap). A vizsgált fajok stressztürési indexe alacsony volt, és hirtelen csökkent a mütrágya koncentráció növelésével (1. táblázat). A GSTI értéke a $3 \mathrm{~g} / \mathrm{l}$-es mütrágya koncentráció esetében 10-15 \% volt, mely jelentősen alacsonyabb, mint a gabonafajták értékei hasonló kezelés után (70-90 \%). Például három árpafajta sótürési indexe $5 \mathrm{~g} / \mathrm{l} \mathrm{NaCl}$ alkalmazásával 67,07 - 91,24 \% között mozgott (Goumi et al. 2014). Ugyanez a paraméter 80 és $90 \%$ között mozgott azoknál a napraforgó fajtáknál melyeket 5 g PEG és $100 \mathrm{ml}$ desztillált víz oldatában csíráztattak (Ahmad et al. 2009).

Az átlagos csírázási időket vizsgálva, szignifikáns különbséget tapasztaltunk a Cyanus segetum $3 \mathrm{~g} / \mathrm{l}$-es mütrágya kezelésénél $(\mathrm{SL}<0,05)$. A Papaver rhoeas csírázási aránya 39 \%-ra csökkent a 3 g/l-es kezelés hatására, mialatt ugyanennél a koncentrációnál a Cyanus segetum mindössze 9 \%-os csírázási arányt produkált $(\mathrm{SL}<0,05)$.

1. táblázat: A csírázási paraméterek változása különböző mütrágyás kezelés (N:P:K 6:12:24 + 8S) hatására két archeofiton faj esetében

\begin{tabular}{|c|c|c|c|c|c|}
\hline & \multicolumn{5}{|c|}{ Cyanus segetum } \\
\hline Kezelés & $P I$ & GSTI (\%) & $M G T$ (nap) & $G S$ & $\boldsymbol{G R}$ \\
\hline kontrol & $1.75^{\mathrm{a}} \pm 0.52$ & -- & $12.06^{a} \pm 21.82$ & 8.29 & $0.52^{\mathrm{a}} \pm 2.71$ \\
\hline $0.5 \mathrm{~g} / 1$ & $0.75^{a} \pm 0.38$ & 42.86 & $12.45^{a} \pm 33.42$ & 8.03 & $0.44^{a b} \pm 1.63$ \\
\hline $1 \mathrm{~g} / \mathrm{l}$ & $1.50^{\mathrm{a}} \pm 0.48$ & 85.71 & $12.26^{a} \pm 18.71$ & 8.16 & $0.39^{a b} \pm 4.79$ \\
\hline $2 \mathrm{~g} / \mathrm{l}$ & $0.50^{\mathrm{a}} \pm 0.25$ & 28.57 & $12.74^{a} \pm 16.18$ & 7.85 & $0.27^{b c} \pm 1.26$ \\
\hline \multirow[t]{2}{*}{$3 \mathrm{~g} / \mathrm{l}$} & $0.25^{a} \pm 0.13$ & 14.29 & $13.00^{b} \pm 8.05$ & 7.69 & $0.09^{c} \pm 1.50$ \\
\hline & \multicolumn{5}{|c|}{ Papaver rhoeas } \\
\hline Kezelés & $P I$ & GSTI (\%) & $M G T$ (nap) & $G S$ & $\boldsymbol{G R}$ \\
\hline kontrol & $14.00^{\mathrm{a}} \pm 5.20$ & -- & $7.32^{\mathrm{a}} \pm 62.64$ & 13.66 & $0.81^{a} \pm 2.50$ \\
\hline $0.5 \mathrm{~g} / 1$ & $10.00^{a} \pm 2.89$ & 71.43 & $8.30^{\mathrm{a}} \pm 62.37$ & 12.05 & $0.72^{\mathrm{a}} \pm 1.71$ \\
\hline $1 \mathrm{~g} / \mathrm{l}$ & $3.00^{\mathrm{a}} \pm 1.19$ & 21.43 & $8.90^{\mathrm{a}} \pm 67.45$ & 11.23 & $0.61^{a b} \pm 4.44$ \\
\hline $2 \mathrm{~g} / \mathrm{l}$ & $2.25^{\mathrm{a}} \pm 1.13$ & 16.07 & $9.61^{\mathrm{a}} \pm 43.90$ & 10.41 & $0.51^{b} \pm 1.71$ \\
\hline $3 \mathrm{~g} / \mathrm{l}$ & $1.50^{\mathrm{a}} \pm 0.75$ & 10.71 & $10.03^{a} \pm 45.27$ & 9.97 & $0.39^{b} \pm 1.71$ \\
\hline
\end{tabular}

Forrás: A szerzők saját szerkesztése. Jelmagyarázat: PI, csírázás gyorsasági index; GSTI, stress türési index a csírázás alatt; MGT, átlagos csírázási idő; GS, csírázási sebesség; GR, csírázási arány.

Az egyes oszlopokban található különbözö betük szignifikáns különbséget fejeznek ki, $\mathrm{p} \leq 0.05$ érték mellett a Tukey teszt alapján. A GSTI és a GS adatok a PI illetve az MGT értékekből származtatott értékek, ezért ezeket statisztikailag nem elemeztük. 


\subsection{Szabadföldi kísérlet}

A fenológiai fejlödésben és a növények méretében nem volt statisztikailag kimutatható különbség a kontroll és a kezelt parcellák között. A talajtakarási értékeket vizsgálva szingifikáns különbséget tapasztaltunk a Cyanus segetum esetében (SL<0,001): 39,27 \% volt a kezelt; és 27,79 \% a kontroll parcellákon. Szignifikánsan nagyobb virágszám volt megfigyelhető (Tukey teszt $\mathrm{SL}<0,05$ ) a Consolida regalis kezelt parcelláin, összevetve a kontroll állománnyal (2. táblázat).

\section{2. táblázat: A virágszámok páronkénti összehasonlítása mütrágyás kezelés} hatására három archeofiton faj esetében

\begin{tabular}{|c|c|c|c|}
\hline Faj & Kezelés & $N$ & $\begin{array}{c}\text { Átlagos } \\
\text { virágszám/parcella }\end{array}$ \\
\hline Papaver rhoeas & kontrol & 33 & $\mathbf{0 . 7 0 5 3 6 1}^{\mathrm{a}}$ \\
\hline Papaver rhoeas & mútrágyázott & 33 & $\mathbf{0 . 7 5 9 1 4 7}^{\mathrm{a}}$ \\
\hline Cyanus segetum & kontrol & 33 & $\mathbf{1 . 7 3 4 2 7 4}^{\mathrm{a}}$ \\
\hline Cyanus segetum & mútrágyázott & 33 & $\mathbf{2 . 1 8 3 1 6 4}^{\text {ab }}$ \\
\hline Consolida regalis & kontrol & 33 & $\mathbf{3 . 5 2 9 4 4 9}^{\mathbf{b}}$ \\
\hline Consolida regalis & mútrágyázott & 33 & $\mathbf{5 . 1 6 2 6 8 5}^{\mathbf{c}}$ \\
\hline
\end{tabular}

Forrás: A szerzők saját szerkesztése. Megjegyzés: N, a vizsgált növények száma. Az eltérő betük szignifikáns különbséget mutatnak a Tukey teszt alapján $(\mathrm{p} \leq 0.05)$.

A Papaver rhoeas virágzási idejének csúcsa (5-ös dekorációs érték) június harmadik dekádjára esett. A Consolida regalis virágzási időszaka május végétől június első dekádjáig tartott. A kicsírázott magoncok 60-100 \%-a díszített ebben az időszakban. Egy mérsékeltebb, második dekorációs időszakot detektáltunk a kezelt parcellákon június utolsó dekádjában. A Cyanus segetum szintén május vége és június eleje között mutatta a legnagyobb dekorációs értéket (5). Ennek a fajnak a virágzási időszaka hosszabb volt, mint a Consolida regalis vagy a Papaver rhoeas virágzása. A búzavirág virágzó egyedszáma folyamatosan csökkent, mialatt az egyedenkénti virágzatok száma emelkedett június végéig. Az egyedszám csökkenés (Baessler and Klotz 2006; Fried et al. 2009), nem volt megfigyelhető a Consolida és a Papaver esetében a rövid vizsgálati időszak miatt. Több kutatás is megállapította ugyanis, hogy mind a lágyszárúak, mind a fásszárúak sokkal inkább toleránsak a sóstresszre idősebb korukban, illetve a virágzás alatt, mint a kezdeti vegetatív fejlődési; csírázási fenofázisban (Läuchli and Grattan 2007; Niinemets 2010). Így az archeofitonok esetében is a mütrágyázás által előidézett sóstressz hatás növekedésével az egyedszám csökkent a növények érzékeny; magonc fenofázisban, amely a kifejlett növények hiányát eredményezte. A kezelt Cyanus és Consolida növények kismértékben magasabbak voltak, mint a kontroll állományok, mely a mütrágyás kezelés hatására kialakult magas biomassza tömegre utal (Bischoff and Mahn 2000). 


\subsection{Prolin tartalom}

Számos környezeti stressz (pl. magas sótartalom) okozhat prolin felhalmozódást (Ahmad et al. 1981, Kubala et al. 2015). Ez a fiziológiai válasz feltehetően a prolin ozmoprotektív és ozmolitikus hatásából ered (Fougére et al. 1991). Képes csökkenteni az oxidatív stressz károsító hatásait és megvédeni a fehérjék szerkezetét (Samuel et al. 2000). A prolintartalom meghatározása megbízható információkkal szolgál a növények aktuális fiziológiai állapotára és stressztürő képességére vonatkozóan (Ábrahám et al. 2010).

Szignifikáns különbséget tapasztaltunk a Cyanus segetum novemberi mintáiban. A kezelt állomány prolintartalma magasabb volt, mint a kontroll $(\mathrm{SL}<0,01)$. Ez a különbség nem volt megfigyelhető a júniusi mintákban $(0,4537 \mathrm{mg} / 100 \mathrm{mg}$ a kezelt parcellákon, $0.4545 \mathrm{mg} / 100 \mathrm{mg}$ a kontroll parcellákon). Ez a különbség nem volt kimutatható a másik két vizsgált fajnál, de az értékek hasonlóan alakultak. A sóstressz hatása csökkent a két mintagyüjtési időpontot összehasonlítva (páros tpróba: $\mathrm{t}=4,504, \mathrm{SL}<0,001)$. A három vizsgált faj prolintartalma magasabb volt, mint a gabonafajtáké (Pyšek and Lepš 1991; Kleijn and van der Voort 1997).

\section{Következtetések}

A Consolida regalis-nak voltak a leggyengébb csírázási paraméterei a laboratóriumi vizsgálat alapján. A Papaver rhoeas és a Cyanus segetum csírázási aránya pedig szignifikánsan csökkent, illetve a Papaver rhoeas stressztürési indexében is jelentős visszaesés volt megfigyelhető a mütrágyás kezelés hatására. Ezen kívül a lassú kezdeti fejlődés is magyarázatot nyújt az archeofitonok eltünésére (különösen a Consolida regalis, illetve részben a Cyanus segetum esetében). A fő virágzási idő május végétől június első dekádjáig tartott, bár egy jelentős második dekorációs időszakot is megfigyeltünk a mütrágyával kezelt parcellákon június végén. Mindazonáltal a Consolida regalis talajtakarása volt a leggyengébb (8-10 \%). Az alkalmazott mütrágyás kezelés nem befolyásolta sem a virágzás hosszát, sem az intenzitását. A prolinkoncentráció vizsgálata során magas sóérzékenységet tapasztaltunk a Cyanus segetum magoncainál, különösen a fejlődés kezdetei szakaszában. Ez az érzékenység csökkenti a túlélési és terjedési lehetőségeit a gabonatáblák mellett. Ez a stresszfaktor tartósan fennmaradhat öntözetlen környezetben, melyet megerősít a novemberi és a június minták prolintartalmának kis különbsége.

\section{Köszönetnyilvánítás}

Köszönettel tartozunk a kutatás támogatásáért, amely az EFOP-3.6.1-16-201600006 „A kutatási potenciál fejlesztése és bővítése a Neumann János Egyetemen” pályázat keretében valósult meg. A projekt a Magyar Állam és az Európai Unió támogatásával, az Európai Szociális Alap társfinanszírozásával, a Széchenyi 2020 program keretében valósul meg. 


\section{Irodalomjegyzék}

Ábrahám EC, Hourton-Cabassa C, Erdei L, Szabados L (2010): Methods for determination of proline in plants. In Sunkar R, ed., Plant stress tolerance. Methods and protocols. Stillwater Humana Press, Oklahoma, 317-331.

Albrecht H (1995): Changes in the arable weed flora of Germany during the last five decades. In 9th European Weed Research Society Symposium "Challenges for Weed Science in a Changing Europe", 10-12 July 1995, Budapest, 41-48.

Ahmad I., Wainwright S. J., Stewart G. R. (1981): The solute and water relations of Agrostis stolonifera acotypes differing in their salt tolerance. New Phytol 87:615-629.

Ahmad S., Ahmad R., Ashraf M. Y., Ashraf M., Waraich E. A. (2009): Sunflower (Helianthus annuus L.) response to drought stress at germination and seedling growth stages. Pak J Bot 41:647-654.

Bischoff A., Mahn E. G. (2000): The effects of nitrogen and diaspore availability on the regeneration of weed communities following extensification. Agr Ecosyst Environ 77:237-246.

Baessler C., Klotz S. (2006): Effects of changes in agricultural land-use on landscape structure and arable weed vegetation over the last 50 years. Agr Ecosyst Environ 115:43-50.

Fougére F., Rudulier D. L., Streeter J. G. (1991): Effects of salt stress on amino acid, organic acid, and carbohydrate composition of roots, bacteroids and cytosol of alfalfa (Medicago sativa L.). Plant Physiol 96:1228-1236.

Fried G., Petit S., Dessiant F., Reboud X. (2009): Arable weed decline in Northern France: Crop edges as refugia for weed conservation? Biol Cons 142:238-243.

George D. W. (1967): High temperature seed dormancy in wheat (Triticum aestivum L.). Crop Sci 7:249-253.

Goumi Y. E., Fakiri M., Lamsaouri O., Benchekroun M. (2014): Salt stress effect on seed germination and some physiological traits in three Moroccan barley (Hordeum vulgare L.) cultivars. J Mater Environ Sci 5:625-632.

Hartmann H. T., Kester D. E., Davies F. T., Geneve R. L. (1997): Plant propagation. Principles and practices. Englewood Cliffs, New Jersey: Prentice-Hall.

Kleijn D., Van Der Voort L. A. C. (1997): Conservation headlands for rare arable weeds: the effects of fertilizer application and light penetration on plant growth. Biol Conserv 81:57-67.

Kubala S., Wojtyla Ł., Quinet M., Lechowska K., Lutts S., Garnczarska M. (2015) Enhanced expression of the proline synthesis gene P5CSA in relation to seed osmopriming improvement of Brassica napus germination under salinity stress. J Plant Physiol 183:1-12.

Läuchli A., Grattan S. (2007): Plant growth and development under salinity stress. In Jenks M. A., Hasegawa P. M., Jain S. M. ed., Advances in Molecular Breeding Toward Drought and Salt Tolerant Crops. Springer, Dordrecht, 1-32.

Niinemets, Ü. (2010): Responses of forest trees to single and multiple environmental stresses from seedlings to mature plants: Past stress history, stress interactions, tolerance and acclimation. Forest Ecol Manag 260:1623-1639.

Pyšek P., Lepš J. (1991): Response of a weed community to nitrogen fertilization: a multivariate analysis. J Veg Sci 2:237-244.

Preston C. D., Pearman D. A., Hall A. R. (2004): Archaeophytes in Britain. Bot J Linn Soc 145:257294.

Saeb H., Khayyat M., Zarezadeh A., Moradinezhad F., Samadzadeh A., Safaee M. (2013) Effect of $\mathrm{NaCl}$ Stress on seed germination attributes of periwinkle (Catharanthus roseus L.) and corn poppy (Papaver rhoeas L.) plants. Plant Breed Seed Sci 67:115-123.

Samuel D., Kumar T. K. S., Ganesh G., Jayaraman G., Yang P. W., Chang M. M., Trivedi V. D., Wang S. L., Hwang K. C., Chang D. K., Yu C. (2000): Proline inhibits aggregation during protein refolding. Protein Sci 9:344-352.

Šarić T., Ostojić Z., Stefanović L., Milanova S. D., Kazinczi G., Tyšer L. (2011): The changes of the composition of weed flora in Southeastern and Central Europe as affected by cropping practices. Herbologia 12:5-27. 
Svensson R., Wigren M. (1986): History and biology of Consolida regalis is Sweden. Sven Bot Tidskr 80:31-53.

Turkoglu N., Alp S., Cig A. (2009): Effect of temperature on germination biology in Centaurea species. Afr J Agric Res 4: 259-261.

Williamson M., Stout J. C., Dehnen-Schmutz K., Milbau A., Hall A. R. (2008): A provisional list of Irish archaeophytes. Ir Nat J 29:30-35.

Zafar S., Ashraf M. Y., Niaz M., Kausar A., Hussain J. (2015): Evaluation of wheat genotypes for salinity tolerance using physiological indices as screening tool. Pak J Bot 47:397-405. 